\title{
1. Framing the debate: London, Beijing and Hong Kong
}

This discussion of Hong Kong is framed in terms of the resources of the classical European tradition of social theorizing, ${ }^{1}$ which is concerned to critically elucidate the dynamics of complex change in the ongoing shift to the modern world. The substantive discussion will focus on the issue of change, and it will seek to grasp the political-cultural logics of elite and popular responses to the changing circumstances of the territory. ${ }^{2}$ It will use materials taken from historical scholarship, political economy and varieties of political-cultural analysis in order to offer a synoptic overview within which detailed issues will be pursued. ${ }^{3}$ These materials will be used to track patterns of change down through time from colonial days to the present. The text will argue that what has happened in Hong Kong is a transfer of power between sovereigns made without reference to the wishes of the local population, one that disregards extant local political-cultural identities and the evident local demands for democracy in favour of readings of events preferred by local elites and their allies in Beijing, both narrower (the local elite's concern for its money) and broader (Beijing's concerns for China's domestic stability and international relations), and that as a consequence the current settlement is inherently flawed. It lacks both realism and legitimacy and is likely to prove to be unstable over the longer run. It cannot be sustained, and after a near twenty-year experiment it could be time for those involved to reconfigure both the local settlement and the links with the distant master in Beijing. Unpacking this thought, a clutch of familiar issues will be revisited in order to illuminate the circumstances of contemporary Hong Kong; they flow from the theoretical concern for change: structures, governance, public politics (along with the issue of democracy) and, finally, the likely future of the extant form of life of the territory.

So, picking up this quartet; first, the demands of the structural contexts within which agents in the territory operate. These are complex and include a number of aspects: (i) political-economic - the territory is lodged within a number of networks, global (thus Hong Kong is a major financial and logistics centre), regional (Hong Kong is situated within established East Asian 'Greater China' networks) and sub-regional (Hong 
Kong is a part of the burgeoning Pearl River Delta area); (ii) sociocultural - the population of the territory is in broad terms Chinese and there are many linkages to the mainland; and (iii) politico-administrative - Hong Kong is now constitutionally ${ }^{4}$ located in China and this opens up the issue of the local politico-administrative elite's relationship with the wider double bureaucracy ${ }^{5}$ of the mainland.

Then second, the nature of the general machinery of governance. This provides the politico-administrative environment within which political agents must work: (i) the juridical and political status of the territory as a Special Administrative Region (SAR); (ii) the precise nature of the local elite's projects for the future (if any); (iii) the machineries of governance (established and effective or not); and (iv) the logics of local politicalcultural life (the possibilities of action).

Third, the characteristics of contemporary political debates about the future of the territory: (i) the question of the nature of the polity and its legitimacy when measured against locally cited notions of democracy (variant liberal democratic or variant state-socialist) and (ii) the nature of the local elite (able to act autonomously ${ }^{6}$ or otherwise).

And then, finally, the overarching issue of the likely future of Hong Kong's established form of life, in particular whether or not it can be sustained in the context of deepening mainland linkages. And here, in the background, the text will entertain an alternative conceptualization of events, that is, whether or not current conflicts can be treated as symptoms of a necessary process of adjustment whereby the periphery and core accommodate the demands embedded within their distinctive historical development trajectories.

\section{ANALYSING UNFOLDING DYNAMICS OF SOCIAL CHANGE}

Any exercise in social theorizing will be bound by context. Any exercise in social theorizing will centre on the work of an active, socially embedded theorist. And any exercise in social theorizing will have an audience in view. ${ }^{7}$ In brief, social theorists make sense; they do not simply describe the world. This has been true of work on Hong Kong. Christopher Munn, ${ }^{8}$ looking at the historiography of the place, identifies two familiar ways of addressing matters: first, an Anglo-centric colonial style of work, and second, its counterpart in work produced by Beijingcentric scholars. They produce inverted versions of the same story whereby outsiders seize territory and build a trading city, but they also have it in common that they overlook the detail of the form of life of the 
city, the actual business of life in Hong Kong. In a similar fashion, one commentator, Siu-Keung Cheung, ${ }^{9}$ invoking Michel Foucault and citing a putative 'Hong Kong School', ${ }^{10}$ has identified a series of contexts within which social theorists have made arguments for particular audiences, and in each of these the place 'Hong Kong' assumes a different guise: first, echoing Munn, the competing discourses of colonial rule; second, the anti-communist discourses of the cold war period; and third, the contemporary period of globalization or empire. ${ }^{11}$ In each case a distinctive reading of 'Hong Kong' is given. In the first noted, the place is either created by an external colonial incursion or contrariwise a longestablished territory is stolen from an all-embracing Chinese motherland; in the second noted, the place is a Western bulwark against an expansionist communism; and finally, in the third noted, the place is a world city within an increasingly or already integrated global neo-liberal empire. Cheung goes on to argue that whilst much can be said about these various versions of 'Hong Kong', what they have in common is a tendency to ride roughshod over the details of the people who down the years have lived and made their lives in Hong Kong, and that in contrast to familiar neglect, this local sphere might be a good place to start. And so, to all this, a fourth discourse can be posited - as indicated - calling attention to the details of the self-construction of Hong Kong, thus affirming the agency of local people, matters to be uncovered in the details of the ordinary lives of local inhabitants; and then, finally, as a parallel complementary argument, a discourse of transferred power - or more harshly transferred colonialism - and the related process of embedding a new political settlement. The general line that will be followed in this text will acknowledge the shifting context of the territory and call attention to the work of active players in Hong Kong; roughly, then, the text will work with the last two discourses.

\section{Reading and Reacting to Enfolding Structural Change}

By way of a starting point, it can be recalled that the global system comprises a shifting network of relationships, or structures of power, ${ }^{12}$ these enfold and run through states and so all political elites ${ }^{13}$ must read and react to the demands of structural change. Elites must plot a route to the future. They must order their populations and legitimize their actions, and the machineries of the state are the means by which this can be done. The state can be thought of as an institutional membrane serving to order trans-state structures of power. This is true of the political elites ruling Hong Kong; however, their situation is somewhat unusual as Hong Kong is not formally a sovereign state. In the past it was a colony and at the 
present time it is a SAR of China, so the political elite of Hong Kong lack the full set of tools of statecraft that other political elites enjoy by virtue of their position within the machineries of sovereign states. Nonetheless, they have inherited extensive local authority and on this basis they must deal both with their own community and with the demands of Beijing. However, dealing with the demands of outsiders is not a new experience for the political elites of Hong Kong, for during the colonial days they had to deal with the demands of London, and it is here that one clue to the nature of Hong Kong politics can be found: the ways in which local elite ${ }^{14}$ agents read and react to enfolding circumstances in order to sketch out a route to the future for the territory, where these circumstances include the intrusive demands of powerful external groups.

The overall direction of travel of any territory - its route to the future - can be grasped in outline as the product of a historical dynamic of structures, agents and projects: ${ }^{15}$ the political elite must read and react to enfolding circumstances, plot a route to the future and appropriately discipline its population (that is, draw them into its project with techniques of organization and legitimation). The trajectory sketched out over time will reflect the sequence of exchanges between domestic political elite agents, their local population and the wider structural contexts within which the territory operates. A historical trajectory will be created by a long-drawn-out and thoroughly tangled process. Matters are inevitably contingent and so there will be periods of relative stability interspersed with episodes of complex change. ${ }^{16}$ The situation that obtains at any one time will be the contingent sum of these relationships: it will be the current configuration. In regard to Hong Kong, all this points to a historical process of the self-creation of contemporary Hong Kong. Some of these themes will be pursued later, but here, by way of a preliminary, calling attention to the structural circumstances of the elite, these remarks suggest three starting points for enquiry: first, descriptions of the nature of the domestic scene; second, a rough characterization of the territory's changing links to China; and third, a note on the particular linkages of the domestic scene with the wider regional and global structural context.

So, first, in respect of the domestic scene, there are various social groups resident within the territory. Cast in terms of social classes there are financial elites, corporate elites, administrative elites and political elites, together the key power holders in the territory; thereafter there are professional middle classes; and finally there are the grass-roots people, plus the marginalized poor. ${ }^{17}$ However, this characterization can be revised by noting a number of further distinctions including religion, ethnicity, education, language, nominal statehood (passport(s)), place of 
origin (in particular, local/non-local) and so on. And, of course, classcommentators make the descriptions their theories/agendas require. ${ }^{18}$

Then, second, links to China are crucial. The formal institutional mechanisms that link the SAR to the metropolitan centre in Beijing are located within the double bureaucracy of the mainland's party-state system. The system is both hierarchical (working top-down) and dispersed (working via subordinate peripheral cores), so power is dispersed and consequently the machinery is home to multiple voices. ${ }^{19}$ The central government can utilize a number of organizations in its dealings with Hong Kong: the National People's Congress (NPC) (with some appointed Hong Kong members); the Chinese People's Political Consultative Conference (CPPCC) (with some appointed Hong Kong members); the Hong Kong Liaison Office (appointed by Beijing); the Hong Kong and Macau Office (appointed by Beijing); the Chinese Communist Party (CCP) (with undisclosed local memberships). The system of governance allows Beijing to select the Chief Executive (CE) of the local administration. Thereafter, the denizens of these machineries are enjoined to affirm an official view of the circumstances of the country. ${ }^{20}$ And finally there is a spread of United Front activities - United Front being 'patriotic groups' which are local Beijing-sponsored groups active in Hong Kong that serve to lodge Beijing's arguments within civil society. In all this, the general issue is the nature and extent of the reach of the Beijing apparatus formal and informal - into the form of life of Hong Kong.

And, third, the structural context encompasses the pattern of linkages of domestic groups to wider contexts, ${ }^{21}$ that is, the links domestic groups have to people and networks outside the territory of Hong Kong. Such linkages can be of different valences: ${ }^{22}$ positive, where the power leans towards Hong Kong, and negative, where the power leans towards outside partners. ${ }^{23}$ Thereafter, the question is one of detail - spelling out the ways in which elite groups within Hong Kong relate to these structural linkages (finance - production - security - knowledge ${ }^{24}$ ), characterizing the valences of these relationships and indicating how these matters play within wider domestic politics, that is, how non-elite groups react.

Social theorists and other commentators can attend to the groups involved in these interactions: they can attend to their particular interests and their linkages with enfolding structures; they can attend to their explicit claims and their records; and they can attend to the trajectories sketched out by their overall communities. In this way some of the structural factors underlying and shaping local politics can be uncovered. Cast in these terms the direction of travel of Hong Kong is now both unclear and disputed. Externally, so to say, it is not clear how Hong Kong 
figures amongst discussions within the Beijing party-state elite and the related policy community. And domestically, there are political groupings sympathetic to Beijing, and there are groups sceptical of the good intentions of the mainland authorities and equally doubting of the agendas of local elites. All this is productive of un-clarity. Yet for social scientific commentary all this points to an agenda; thus the elite must read and react to enfolding change. This is in process. Beijing has appointed the first three CEs of the territory, and it exerts very significant influence over membership of the administration. The city is slated in their terms to remain an economic city and not become a political city. However, the process of adjustment to the requirements of the new distant master has proved to be difficult. The three CEs are widely taken to have failed, and whilst two of them were local businessmen, so their failure is unsurprising, the remaining figure was a previously wellrespected senior civil servant whose term ended with formal enquiries into his probity. Moreover, the local people, far from remaining quiescent, have engaged in a series of very public protest movements, and tens of thousands of people have marched against the proposals or activities of local elites and their Beijing party-state backers. The system is widely taken to be dysfunctional. The current settlement is failing.

So, finally, these preliminary reflections produce an overarching agenda. Four issues can be pursued: characterizing the process of embedding a new settlement; detailing the work of the machineries of governance; unpacking debates in regard to the matter of democracy; and addressing the deeper question of whether or not the local form of life will endure.

\section{FRAMING THE DEBATE ABOUT HONG KONG: SOME AVAILABLE IDEAS CONSIDERED}

Theorists ${ }^{25}$ of international political economy ${ }^{26}$ suggest that it is possible to identify structures (given distributions of global power, read as systems and given for any single actor) and the agents that must deal with these structures (states, multi-national corporations, international organizations, international financial institutions, non-governmental organizations (NGOs) and the like) in pursuit of their several projects. The actions of these various agents in total comprise these self-same structures that frame their activities. Anthony Giddens tagged this 'structuration', the social process of making structures. ${ }^{27}$ In all this, it is usually powerful agents such as states, multi-national corporations, international organizations and international financial institutions that are most important. 
Among these the key agent would be the state. ${ }^{28}$ This requires that one can be identified. In turn, this implies that it is possible to identify an elite (a group in positions of power within the machinery of the state), distinguish them from the related masses and identify the institutional apparatus of a functioning polity. Cast in these terms, it is clear that 'the state' is not a simple, clear and obvious entity; rather the reverse: it is an elaborate contingent construction ${ }^{29}$ which cannot be taken for granted.

The scheme of structures, agents and projects - with the state as the key agent - can be deployed usefully in many circumstances, but in the case of Hong Kong the status of the substantive addressees of the terms the nature of the state (clearly established or not), the nature of the elite (able to act independently, or not), the nature of the polity (coherent and sure of itself, or not), and the nature of the elite project (discernible, or not) - are quite unclear. Plus, there is the matter of the looming presence of Beijing, with its opaque elite politics and the formulaic pronouncements of authorities variously lodged within the elaborate machineries of the party-state and related public sphere, which has a key role in the politics of Hong Kong.

Here a number of these familiar terms can be canvassed, ways of thinking about Hong Kong, their applicability can be considered, then one obvious alternative conceptualization can be noted.

\section{Hong Kong: State, Nation, Country, Polity and Empire}

In the case of Hong Kong the familiar vocabulary of political analysis can be invoked, and a number of ideas are available (state, nation, country, polity and empire), but it is far from clear that they can be put to work. Thus state and a nation: the former a sovereign politico-juridical unit within the international system of states, the latter an imagined community. Popularly, the one dwells within the confines of the other. Social theorists would reverse the relationship arguing that states make nations so as to order populations and legitimate elite power. ${ }^{30}$ Either way, the two are quite routinely linked, thus 'nation-state'. Another idea is also available, but less used and less clear: the notion of a country. It calls attention to people and geographical place. During the phase of the expansion of European state-empires in Southeast Asia, the incoming Europeans spoke of 'country powers', pointing to local polities, not states, not nations, but coherent political units occupying definite - if loosely defined ${ }^{31}$ - territories. And running up the scale a further notion is available, empire: a large, also loosely defined, territory comprising many subordinate communities oriented towards a metropolitan centre, and where the organizational possibilities are many, thus direct rule, 
indirect rule, claims to trustee status, declarations in favour of assimilation and so on. But given these terms, all serving to grasp the nature of political communities, it can be asked: how does Hong Kong fit? What sort of entity is it?

So, first, Hong Kong is not an independent sovereign state - it has a non-standard politico-juridical status. In the past it has been formally a part of a state-empire ${ }^{32}$ system centred on London and characterized as a Crown Colony, ${ }^{33}$ and at the present time it is formally a part of the People's Republic of China (PRC) centred on Beijing ${ }^{34}$ and characterized as a SAR. But in both cases, in practice, it has been remote, in terms of its local form of life, from the metropolitan centres of these two distant powers. It has lain at 'the edge of empires' 35 and so has sustained its own form of life (the sum of economic, social, political and cultural practices). It has also made some sort of coherent polity; that is, it has had a sense of its separateness from wider structures of power and its ability in significant measure to order its own affairs, in brief, its own distinctiveness.

In a similar way, second, Hong Kong is not a nation. The inhabitants do have a strong sense of themselves but their political community has never had access to those state machineries (or analogues) which can serve to foster an imagined national community; rather, the common local identity is that of the inhabitants of a great city, thus, for example, the people who live in Paris are Parisians, or those in Berlin, Berliners, and so on. Yet where for Parisians their nation is France, or for Berliners, Germany, the analogical invitation fails in respect of the people of Hong Kong. They are 'Hong Kongers', ${ }^{36}$ but they are not, or at least not all or even a majority of them, Chinese, in the sense of being Chinese nationals, ${ }^{37}$ much less Chinese nationalists, where both terms would point to an identification with the PRC. Indeed, it is routinely labelled and thus differentiated as 'the mainland', with its inhabitants the 'mainland Chinese' or 'mainlanders', that is, separate.

And, third, Hong Kong might be treated as if it were a country: a place (geography plus people) with a population aware of its distinctive form of life (identified by insiders and identifiable for outsiders) and happy to assert its cultural autonomy. Cast in these terms, Hong Kong has occupied a definite territory for some 150 or so years. It has its own boundaries, it has its own elites, it has its own government, it has a population aware of itself and its own interests, and it has a distinctive history (and can tell stories about it). But notwithstanding these attributes of a country, it does not have an independent state machinery and nor does its elite or population lay claim to nationhood - so it would be an unusual country. Unlike, say, Singapore, which is, insofar as any small 
country can be within the global system, independent and master of its own destiny, Hong Kong must negotiate its route to the future with a powerful distant master - in the past, London, now, Beijing. ${ }^{38}$

Then, fourth, Hong Kong might be seen as a polity. Local Hong Kong elites have had to manage relationships with distant masters; they have had to read and react to their demands, formulate plans and legitimate them amongst their population. The ways in which the local elites have managed these relationships have shaped the resultant local polity: in the case of Hong Kong a tangled process (many awkward external linkages and domestically shifting subaltern groups) creating thereby a distinctive Hong Kong polity. Its people remain 'Chinese' in terms of ideas of ethnicity (pointing to language and inherited cultural practices, which are signalled in routine by physiology - having 'black hair' or 'looking Chinese ${ }^{39}$ ) but here too distinctions are drawn: ethnic Chinese-ness is not a simple given, it is contested. ${ }^{40}$ In the case of Hong Kong, 'ethnicity' does not override identification with a city, hence 'Hong Kongers'.

Thereafter, fifth, the business of empire offers an alternative way of reading the circumstances of the territory and people. It can be noted that during the modern period Hong Kong has been a part of two large political units: the first, a state-empire centred on London, the second, a distinctive party-state system centred on Beijing. In 1997 power over the territory was simply transferred from one elite to another, both external to the place itself, a process obliging both local elite and masses to adjust as best they could in what was a historically unusual process.

In sum, the situation is paradoxical. Thus, domestically, there is a Hong Kong polity and many elements of independent nation-statehood are present: first, it does have much of the machinery of a state (executive, legislature and judiciary); second, it has a population with a strong sense of itself, a population that has received waves of migrants; ${ }^{41}$ third, it has occupied a well-defined territory for some 150 years (that is, to be precise, most of the period of the contemporary modern world). But externally there are significant constraints that cut against its status as a coherent Hong Kong polity, and whilst it is true that all elites are constrained, that is, they must read and react to enfolding structural circumstances and order their population, here the constraints are unusually visible, in particular in the guise of the machineries of rule by distant masters. Contemporary Hong Kong is subject to the sweeping claims of Beijing: claims to juridical oversight (the Basic Law was promulgated by the NPC and it is a part of Chinese law), claims to political oversight (the Basic Law specifies the outline of the local political institutions), claims to military oversight (a garrison of soldiers 
is situated in the territory), and claims to cultural oversight (United Front propaganda insists that the people of the territory are subject to the moral and cultural priority of the Chinese motherland). On these grounds, Beijing evidences a disposition towards routine interference in what otherwise would be regarded as domestic or internal political matters in Hong Kong.

It is not easy to answer the question of the nature of the Hong Kong polity, so a slightly different approach can be pursued: in place of questions of type, matters of practice. Hong Kong has prospered at the edge of empires. So how has the Hong Kong polity dealt with distant metropolitan elites? How have local elites managed crucial relationships with London and now Beijing? And if it is assumed that the local elites have had a measure of coherence and have sought to create a maximum room for manoeuvre - for their own goals as well as collective goals how have they done this? And how have they dealt with the local population - what mix of law, regulation, persuasion and force has been used to secure their support, or where this was either not available or not needed, their acquiescence?

In brief, how have local elites and the local population together dealt with distant masters and created a changing but distinct 'Hong Kong polity'? Casting matters in these terms draws enquiry back to the four issues noted above - embedding, governance, democracy and the local form of life. However, for the moment, there is one further set of ideas to note - this set addresses the business of the 1997 transfer of power.

\section{The Wider Linkages Considered: Transferred Colonialism}

The 1997 transfer of power has been addressed in several ways. First, as an exercise in decolonization, that is, the retreat of a foreign colonial power and the parallel emergence of a local elite concerned with the task of creating or fostering the emergence of a nation and thereafter serving its development. Following decolonization, the territory in question secures 'independence'. Then, second, the idea of retrocession, a technical legal term focused on the transfer of sovereignty that carries the implication of simply reversing an earlier agreement - the opposite of ceding power; here there is an implied equivalence or symmetry such that any substantive differences in the conditions of the territory are elided. And the related, third idea of a return to the motherland of territory and people with the implication of the natural overcoming of an otherwise presumably regrettable earlier sundering of the two communities both of whom are now presumably happy. All these ideas can be reviewed. All have benefits and dis-benefits. The latter outweigh the former. In 
contrast, a more substantively accurate characterization of the events in question might be an idea of the 'transfer of power' or more directly 'transferred colonialism' - an arrangement in respect of the territory that was and is acceptable to the two sovereign contracting parties, London and Beijing.

\section{(i) Decolonization}

In recent times, that is, post-1945, the term decolonization has referred quite directly to the end time of the European state-empire system, ${ }^{42}$ when large multi-ethnic territories ordered around a key central power dissolved away and produced a number of successor political units. ${ }^{43}$ These patterns of dissolution were contingent. Aspirant local replacement elites vied for position, sought support where they could find it (maybe from the departing metropolitan power, perhaps from another external power) and mobilized the population they sought to control/rule in terms of a basic political deal - popular support in exchange for the elite striving to provide better lives. The end result (or, given that politics continues, the provisional result) was the shift from being a territory within a state-empire system to being an independent state within the contemporary international system, that is, decolonization or in brief popular terms, the winning of independence.

But, quite clearly, this did not happen to Hong Kong in 1997 because what did happen was a transfer of macro-level sovereign power from one external authority to another external authority - from London to Beijing - with an explicit expectation of domestic continuity. If the notions of colonialism and decolonization are to be invoked then the correct form should be transferred colonialism. If it is viewed this way, it is easy to see why the transfer of power from one distant master to another should be the occasion of popular domestic Hong Kong unhappiness and the core reason for the many difficulties occurring in their relationship with Beijing (and the people from that polity, those tagged by Hong Kong people as mainlanders). All that said, in relation to these points, mainland commentators cast these matters quite distinctively, and the official line for they all seem to run down a similar track, and given its inherent social scientific implausibility it can be assumed to have been authoritatively spelled out - comprises two aspects: the politico-juridical line is that China has resumed sovereignty, ${ }^{44}$ whilst the race-nationalist rhetoric is that Hong Kong has returned to the motherland, that the territory and people living in it have been reunited with their compatriots and that the people of Hong Kong are Chinese and they have returned to China. 


\section{(ii) Retrocession}

As noted, one familiar way in which the transfer of power was characterized was in terms of the notion of retrocession. In simple terms this points to a politico-juridical process whereby what had been ceded from one sovereign to another was now retroceded, that is, power was transferred once again, back to the original authorities. In the case of Hong Kong, the Qing ceded power to the British who in turn retroceded it to the People's Republic.

But two lines of commentary are opened up at this point. First, as Tony Carty ${ }^{45}$ points out, Beijing has not accepted that the treaties signed by Qing authorities were reasonable; rather, they were 'unequal treaties' and thus repudiated, so 1997 marked the resumption of an interrupted Chinese sovereignty. On the face of it, such reasoning disposes directly of the notion of retrocession. It creates new problems, for claims about 'unequal treaties' did not emerge until the 1920s - some eighty years after the event - and are best read as political polemic (even if those disposed to using these terms do have a point). It also opens the way to a further layer of un-clarity: thus in the Joint Declaration London spoke of the restoration of sovereignty to China, whilst Beijing spoke of its resumption of sovereignty. Then, second, even if the notion is accepted, the retrocession was not a transfer of power to the original authorities because there is no Qing government and its successor state was the Republic of China, which does exist and is located in Taiwan. Thus Beijing's claim seems to be at third hand. In brief, the politico-juridical line of argument is clouded with uncertainty, in practice reducing to shifting international political relations. What is clear is that during the Sino-British negotiations, Beijing insisted that these discussions were conducted at state-to-state level, that is, the population of Hong Kong was denied any independent representation. On the face of it, the narrowly legal line about retrocession has the merit of coherence setting aside the two issues noted - but as with the claims about returns to the motherland it fails in respect of popular legitimacy because the Hong Kong people were not given an opportunity to assent to the retrocession or, contrariwise, to withhold consent.

\section{(iii) Return to the motherland}

The return to the motherland is a familiar characterization. It is a race-nationalist rhetoric. Beijing spokespersons cast matters in a distinctive political-cultural form: they assert that Hong Kong has returned to the motherland; they assert that the territory and its people have been reunited with their mainland compatriots; and they assert that as Hong Kong people are Chinese then it is appropriate that they have returned to 
China. The last noted claim grounds the package. The argument strategy is familiar. Formally it is reductive - social and cultural identity is grounded in naturally given race so that to be Chinese is to be a part of a naturally given community and not a socially constructed or imagined community. However, in practice, it seems to have only a limited grip on the imaginations of Hong Kong people - witness, say, the popular reaction to incoming flows of mainland tourists. In brief, the package is an official nationalism. It may be that the argument carries weight amongst the nationalist minded in the mainland. It may be that the argument carries some weight amongst less well-informed members of the party-state elite. But there is reason to believe that it does not carry much conviction amongst the majority of the people of Hong Kong other than pro-Beijing patriots - as the city has a politically sophisticated population.

\section{(iv) Transferred colonialism}

If decolonization, retrocession or return to the motherland do not grasp what has happened to Hong Kong, then matters could be cast in more realistic terms as a transfer of power. However, this reading risks making a deeply political exercise seem like an administrative matter - the exercise is politically de-natured - so a more accurate characterization of the unfolding dynamics points to a process of transferred colonialism; that is, authority has moved from one elite to another, both external to the place itself, ${ }^{46}$ and the territory's condition remains in essence the same: it was a colony, it is a colony. A number of symptoms of this condition have been identified by commentators and they revolve one way or another around the lack of societal consensus about the future of the territory. One step back, so to say, they note the inadequacy of extant mechanisms in respect of the goal of a consensus, and, one step further back, they note deep unease about the intentions of the elites in Beijing. C.A. Jones, ${ }^{47}$ noting that the colonial authorities were never that bothered about democratization, substituting the notion of the rule of law, sees Beijing's project as 're-colonization' as the mainland's linkages with the SAR deepen. There are three interlinked areas of concern, which can be summarized in terms of economy, society and polity.

(a) First, economic links with the mainland These are long established and they are deepening; indeed, these local networks were one reason why the British took an interest in the territory, and they were one reason for the place's subsequent success. There has been a sequence: trade, investment in manufacturing across the border, lately the Closer Economic Partnership Arrangement (CEPA) and, looking to the future, the 
development of the Pearl River region. Hong Kong businesses and thus people are deeply involved. However, these networks are not straightforwardly beneficial to all, and an argument can be made that local business groups are disinclined to take a collective view on the development of these links whilst in the meantime some are able to take quick business advantage. Thus, for example, the expansion of private hospitals providing obstetrics services on the open market to a client group comprising many mainland mothers (whose Hong Kong born children automatically gain Hong Kong identity and can thus access the city and its welfare systems). Or, again, the property sector, which has development projects in the mainland and in Hong Kong, serving a new affluent clientele, to the detriment of the general provision of housing for local citizens in Hong Kong. Or the tourism sector - sharply criticized in recent years - which has been happy to receive unrestricted flows of mainland tourists, thereby producing private profit and low-grade employment opportunities with the social costs - loss of amenity, low-grade development - placed upon the general population.

(b) Second, social links with the mainland Historically, these are firmly established. The border between Hong Kong and the mainland has been porous for most of its existence and once again these links served the incoming power, the British, who in any case could not have prevented them. The border was more firmly controlled in the years following the end of the Chinese Civil War and the episode of the cold war, and cross-border flows diminished sharply but never ceased as inward migration continued. Today, after reunification, they are once again increasingly vigorous, but now in the context of elaborate modern state machines, that is, monitored/controlled: there is a large cross-border flow of people every day, for employment, schooling and for business and so on. The numbers are large: some two to three hundred thousand border crossings each day. ${ }^{48}$ More visibly, the easing of border controls has seen the numbers of tourists from the mainland increase dramatically, and this has led to complaints from local people (picked up now by government in terms of capacity). Again, visibly, the easing of border controls has also produced a new cross-border informal sector, smuggling, the people involved often being termed 'grey traders'. It is an organized business involving several thousand operatives directly involved in the individual rail or bus transport of goods from Hong Kong into Shenzhen (there are some reports also of vehicular smuggling and occasionally smuggling by power boat). The grey traders have aroused the ire of locals as they are visible, regarded as a nuisance and have been largely tolerated by 
relevant authorities. A small riot in September 2012 occasioned something of a change of policy, that is, a minor toughening up of regulations, and further small riots took place in 2014 and 2015. At this point, it was announced that the trade would be more tightly policed and some action was taken to control the activity, in particular, stronger enforcement of transport regulations, more stringent border checks and the active disruption of grey trade operations; however, notwithstanding, the traders could still be found in many shopping malls. The cross-border trade had become an established lucrative instance of what development economists tag the 'informal sector', and for the participants it was relatively well paid informal work whilst for the organizers it was a lucrative business.

(c) Third, political links with the mainland Again, not new, various authorities on the mainland never relinquished their claims upon Hong Kong; in the 1920s treaties were repudiated as 'unequal treaties'; the Kowloon 'walled city' survived until reunification; and in a more public and popular fashion, mainland politics were picked up locally and so events in China could spill over into Hong Kong. The conflicts between Chinese nationalists of various persuasions and colonial powers spilled over and there were strikes and boycotts in the 1920s. In a similar way, the conflicts between the Kuomintang and the Communist Party also spilled over into Hong Kong, whilst officials in the territory tracked a careful path, that is, endeavoured to be neutral and thus provided a kind of safe haven for those active on the mainland. After the civil war the local area was nominally represented in the NPC, and today, posthandover, the mainland is ever more visible and this seems to be part design, as the denizens of the Beijing-centred party-state machine press forward, and part the consequence of (related) local inaction. Local political agents seem to be unable to fashion a coherent prospective response to their circumstances - its own view of its own future - and so instead disparate issues are tackled ad hoc. At the present time, local commentators argue that local politics is stuck: some point to the local elite; some point to the local administrative structure; and some point to relations with Beijing. Prospectively, whilst some call for political reform, others call for better communication with Beijing.

In sum, the assumption of sovereign power by Beijing opens up two lines of questions: retrospective, how to characterize this assumption of power, and here in this text the preference is for the notion of transferred colonialism; and prospective, how is the new settlement going to be put into practice, that is, how are the elite and the masses in Hong Kong 
going to deal with their new distant master; questions of embedding, governance, democracy and the persistence or otherwise of the local form of life.

\section{HONG KONG: NEWER DEBATES}

If, as commentators argue, ${ }^{49}$ both the departing colonial power and the incoming power sought the convenience of continuity, that is, Hong Kong dominated by its business and administrative elite with institutions kept in place, so too the population, then they failed to consider the changing aspirations of the local population. It may be, as one commentator suggests, ${ }^{50}$ that these locally originating demands were fostered by the departing colonial power; nonetheless, the sentiments (and instruments of social mobilization) are undoubtedly real, that is, up and running. And, as noted earlier, four issues in particular can be pursued: first, changing structures and the process of embedding a new political settlement, that is, the presence of Beijing in Hong Kong; second, the machineries of governance and the question of the sustainability of an executive-led system; third, public politics and the business of democracy where there are contending versions, roughly, a (variant) form of liberal democracy and, contrariwise, a (variant) form of party-state governance; and fourth, the business of political-cultural identity, the self-understandings of people in Hong Kong, that is, the distinctiveness of their form of life, matters which inevitably frame their reactions to any public political issue.

\section{The Contextual Logic of Local Political Life: London, Hong Kong and Beijing}

John Carroll ${ }^{51}$ argues that Hong Kong was created in the space between two nineteenth-century empires: the British Empire and the Qing Empire. The seizure of the geographical island of Hong Kong by the British - a matter of war against the Qing - let them create an economic base in the Pearl River. It was a base controlled by the British, and they asserted their authority over the newly acquired territory. Arguments made by Qing officials to the effect that any resident Chinese should enjoy the protection of Chinese law were rejected. The British occupation of the territory and its affirmation of its law and trading practices (free trade plus a free port) underpinned its rapid success. Two flows of migrants were important, incoming Europeans and incoming Chinese, and it was the interaction of these two groups that created contemporary Hong 
Kong. The exchange had multiple aspects: the British administration controlled the local means of effective violence (military and police); the British authorities secured locally effective law and trading practices; and the British trading houses controlled access to the wider networks of the empire. The Chinese traders were the gatekeepers in respect of access to the mainland. These traders were active along the coast of China and southwards to the island territories of Southeast Asia, and as they were familiar with the British traders, trade through Hong Kong was built on cooperation. Formal membership of the local political elite was by invitation. This was initially British, but later on successful Chinese merchants were invited to participate in elite decision making. The social counterpart was a variant of a typical empire port city with ethnic segregation and quasi-separate development. Thus the Europeans organized themselves in terms of nation and class. The Chinese organized themselves via clan groups, language groups and commercial occupation groups, plus there were community-level facilities such as a temple and a hospital.

The colony prospered between these two empires, so its distinctive domestic character comprised a mix of London, Beijing and the activities of the local, predominantly Chinese, population. In the inter-war period London considered handing power to Nationalist China. In terms of the overall system of empire it was an outlier, and in the run up to the Pacific War the territory was treated as a military liability, yet after the war London insisted on recovering control. ${ }^{52}$ The motivation for this apparent reversal in policy thinking has been unpacked in terms of elite-level, taken-for-granted, political-cultural commitments to the idea of empire, and critics suggest that all this was both unconsidered and foolish. Nonetheless, the British resumed control. Hong Kong prospered. However, the 1997 handover changed the situation. London's influence receded sharply, reducing, formally, to a responsibility to check on the delivery of promises made in the Sino-British Joint Declaration. Beijing's influence moved to the centre and the Basic Law was promulgated by the National People's Congress Standing Committee (NPCSC); it is a part of Chinese law. The political slogan used in connection with the handover was 'one country, two systems'; however, as the domestic and regional politics of the territory were reconfigured - new networks, new sets of ideas and new ideas about routes to the future - those networks that ran along the Beijing-centred machinery became more important. Beijing's voice within the territory became ever more noticeable. There were no signs that the Hong Kong business and administrative elite were worried as the deal on the face of it had given them more not less power in Hong Kong, but the wider population noted economic and political problems 
and the clumsy pursuit of Article 23 legislation provoked a mass demonstration. Commentators argue that from this point onwards Beijing took more (not less) interest in the territory and so commentators began to speak of 'one country, one and a half systems'.

\section{Governance: The Formal Character of Local Politics}

Formally, as the British moved in, the territory acquired a governor, an Executive Council (Exco) and a Legislative Council (Legco) - plus an apparatus of civil service administration. The system took shape in the last few years of the nineteenth century. ${ }^{53}$ London appointed the governor and the colonial civil servants, and, thereafter, local people were drawn in via co-option. Gavin Ure ${ }^{54}$ makes it clear that from the 1920s onwards the local business community was very influential. The system continued down into the late years of colonial rule and one commentator tags it a 'liberal autocracy'. ${ }^{55}$ To this can be added a vigorous civil society. The system has continued across the handover. The crude pattern in Hong Kong is one of an entrenched business elite, which for narrowly pragmatic reasons has allied itself to Beijing, confronting an active population that understands itself in terms of the political-cultural notion of Hong Kongers. The formal machinery serves to protect the local elite. However, local scholars have unpacked the logic of this arrangement and diagnosed built-in flaws: the CE lacks legitimacy, the Legco lacks power and Beijing's role is unclear and its legitimacy disputed. All in all, it is not a recipe for stability or progress.

\section{The Idea of Democracy Unpacked}

The sequence of wars that took place in the first half of the twentieth century reordered global politics as systems of formal empires dissolved away (European, American and Japanese) and local elites sought power, promising statehood and development. Territories hitherto lodged within these empires secured political independence as new states. All new states sought to join the United Nations (UN), itself a distinctive organization, carrying the imprint of its construction, essentially made to serve a liberal global system (economic - liberal markets; political liberal democracies) but pragmatically embracing all states. Its membership has expanded and today it has around 200 members, and for present purposes, it can be noted that the bulk of the member states affirm the notion of democracy. Clearly, the notion admits of a wide variety of interpretations. 
The idea of democracy has been widely debated. David Held ${ }^{56}$ offers a survey of the Western tradition, starting with Greece/Rome, noting seventeenth-century England, Enlightenment France (and America) and going on to note further developments in the liberal-democratic tradition. More critical voices are available: the communitarianism of Alasdair MacIntyre, ${ }^{57}$ the distinction between liberalism and democracy made by C.B. Macpherson, ${ }^{58}$ plus, more recently, the notion of discourse democracy associated with Jurgen Habermas. ${ }^{59}$ Other names could be mentioned, ${ }^{60}$ however, rather than debate the idea in the abstract, the notion can be returned to the practical realm of politics - treated as a working idea; in this sense, the notion, in all its practical diversity, can be unpacked in terms of a trio of headings: democracy-as-philosophy (the abstract formal debates of political philosophers and ideologists); democracy-as-institutional machinery (the benefits and dis-benefits of various designs of systems of governance, measured against various schedules of evaluative criteria); and democracy-as-actual-historical achievement (the substantive records characterized and judged). ${ }^{61}$

Cast in these terms, the elite and masses in Hong Kong are engaged in a long-running debate as to the nature of the political community that they presently inhabit: its origin, logic and possible futures. Opinions differ. The local elite, backed by Beijing, which opposed earlier attempts at democratic reform, ${ }^{62}$ is broadly concerned to protect the status quo (opinion is not uniform - some functional constituencies have favoured reform). Professional groups offer pragmatic support. The territory has an essentially colonial system where a narrowly constituted elite rules a demobilized population via a technically competent administrative machine; in the case of Hong Kong, commentators have dubbed the system a 'bureaucratic polity'. In contrast, the masses are divided. Patriotic forces lend their support to the elite drive for continuity, whereas the majority (as indicated in those areas of liberal-democratic competitive elections that are held - plus opinion polling) look for reform along some sort of liberal-democratic line, matters to be pursued via reformed machinery of governance, in particular, an empowered and democratized Legco (electoral reform) - but resisted by the local elite and Beijing - and now increasingly in the form of popular political and cultural resistance to mainlandization. As with other aspects of contemporary politics, it is not easy to guess how debate or practice will unfold; however, the notion of democracy provides one more thread around which the discussion carried in this text can be organized matters to which the text will return later. 


\section{Political-cultural Identity ${ }^{63}$ the Future of the Form of Life}

The notion of political-cultural identity points to the ways in which actors conceive their relationship to their wider political environment; how they fit into their local polity. It is not simply instrumental (who makes demands upon an actor and what demands can be made in return), or formal-institutional (what is the formal status of a member of that community and what obligations/rights are attached), but also cultural (what is the nature of the polity, its denizens and what thereafter is allowed/disallowed to any single individual). Any political-cultural identity is socially constructed: there are routines of learning (informal and formal whereby individuals are located within wider social networks), there are routines of ongoing re-affirmation (rituals surrounding the national past), and there are also, inevitably, routines of disenchantment and disengagement for those who for one reason or another leave the polity (dissidents, émigrés, sojourners and so on ${ }^{64}$ ).

The notion of political-cultural identity can be unpacked after the style of cultural studies analysts ${ }^{65}$ using the trio of locale, network and memory. Cast in substantive terms: first, it points to the immediate neighbourhood within which a person operates (in particular, grows as a child) - it is an arena rich in meanings; second, it points to the wider networks within which any person will operate - networks involving kin, or friends, or relatives, or casual acquaintances - all those links that involve the person in question moving outside their immediate locale; and third, it points to the ways in which the creative business of active remembering and forgetting melds routine experience into memory. In these terms, it is clear that any member of a polity will have a rich idea of the nature of that polity, built from the ground upwards and lodged in routine experience. In the case of contemporary Hong Kong, a cultural studies route into enquiry indicates a diverse population: (i) there are groups resident from Hong Kong's colonial days when it was a trading port visited by many such groups, some of whom stayed; (ii) there are groups resident from post-war cold war days, in particular migrants fleeing violence on the mainland; and (iii) there are groups recently arrived, post-1997, leaving the mainland in search of better material standards. And all this creates a social environment whose members can claim divergent histories.

The notion of political-cultural identity can also be unpacked in terms of the interacting logics of competing groups within the polity - simply, elites and masses. This style of enquiry pulls away from the substantive detail demanded above and moves instead into the more abstract or formal or ritual ideas affirmed and sustained by particular groups within 
the polity - here, in particular, abstract general claims about a polity, the creation and re-affirmation of collective memory and the national past. In this fashion, a schematic process can be uncovered: elite sponsored ideas (serving the interests of the elite) interact with the ideas lodged in the common experiences of the population and the resulting intermixing produces a national past, a contingent agreed view of the nature of the polity comprising a set of ideas to which all will give provisional assent. In the case of contemporary Hong Kong, a collective memory and national past route into enquiry involves two streams, and the former could include many groups - schools, hospitals, banks, business groups and so on - but it is the latter that is relevant here for the national past tells a polity where it came from, what it is and where ideally it is going. At present the visible clash is between two national pasts: those who accommodate themselves to the leadership role of Beijing, the patriotic Chinese; and those who cleave to the vital legacies of the distinctive historical trajectory of the territory, Hong Kongers.

All this is an arena of active contestation and it is not clear how it will be resolved.

$* * * * * * *$

Debates about Hong Kong's exchanges with China, the nature of Hong Kong governance, the business of democracy and the future of the territory are all up and running and they revolve around the business of living with a new distant master. A process of embedding a new political settlement can be posited and, given the scale and sweep of the implied changes to extant links, ideas and routines, it could be expected to be something other than smooth and unproblematic, rather the reverse, a tricky and fraught process. Thus far, in the case of Hong Kong the process seems to have gone badly. Beijing has appointed three CEs and all have failed. The system is flawed. Beijing's performance to this point can only be described as inept; however, after some twenty years of failure, it may be that the party-state elite and the related policy community will take note - Beijing has tried pulling the strings but the strategy has failed. Beijing cannot simply absorb Hong Kong, the local and international risks would be too high, so the alternate route is dialogue. In Hong Kong 'think tanks' proliferate and newspaper columns are full of proposals. It could be that there is space for a post-rejection conversation but this would require Beijing to engage. 


\section{CONCLUSION: LIVING WITH NEW DISTANT MASTERS}

How all these matters will be resolved is unclear. Social scientists cannot predict the future - that is a game for natural scientists - and the best social scientists can do is sketch out scenarios: sets of statements about what might happen if certain agents act in certain ways in response to enfolding structural conditions. And so attention turns to structural circumstances, key political players, their social bases, institutional locations, interests/ideologies and thus anticipated projects. One wellinformed text ${ }^{66}$ suggests a coincidence of intentions at elite level around the time of the transfer of power, that is, both departing and arriving colonial powers sought continuity - specifically, local elite-level domestic control together with popular acquiescence, with this local control supplemented as necessary by the new distant master. In this way the economic networks based in Hong Kong and running both into the mainland and more broadly into the global trading system would not be disturbed - it would be 'business as usual'.

However, the scheme has gone awry through a mix of unlucky circumstances (the unexpected and damaging 1997 Asian Financial Crisis plus the initially mishandled SARS epidemic ${ }^{67}$ ), local elite incompetence (the work of the first three CEs chosen by a small circle election dominated by Beijing, or, to the point, the three CEs chosen by Beijing) and the obtuseness and ineptitude of the denizens of the mainland party-state machine and associated policy community (in particular, the habit of using a declarative tone towards a polity habituated to debate, the habit of using United Front techniques seeking to engineer solutions in a polity more used to debate and networking ${ }^{68}$ and the habit of responding to local reverses in terms of the blame game (blaming the non-patriotic, blaming foreigners, blaming under-schooled youth and so on)). All this has worked to undermine elite hopes for untroubled continuity. Various local groups now loudly affirm the ideal of democracy: new parties, picking up statements made in two documents in regard to local accountability and democracy - the Sino-British Agreement and the Basic Law; popular pressure groups exercised by this or that issue, lately, 'grey traders'; and, most recently, taking shape after the NPCSC's declarative statements in regard to electoral mechanisms for the $2017 \mathrm{CE}$ selection, mis-described as 'universal suffrage', the student-led popular Occupy Central or Umbrella Revolution. All are wedded to the goal of institutional reform. What seems to be sought is a greater measure of liberal-democratic type democratization - the better to serve the interests 
of local people; however, local elite foot dragging, seemingly backed for whatever reasons by Beijing, suggests that neither the local elite ${ }^{69}$ nor Beijing are minded to respond favourably.

\section{NOTES}

1. P.W. Preston 2009 Arguments and Actions in Social Theory, London, Palgrave.

2. On political-cultural ways of understanding and acting, see P.W. Preston 1997 PoliticalCultural Identity: Citizens and Nations in a Global Era, London, Sage.

3. The particular theoretical machineries are taken from a number of closely related streams of enquiry and reflection: first, political history (the widest and necessary frame of political analysis as all contemporary agents read their presents in terms of ideas inherited from the past - in the case of Hong Kong, the history of the interactions of two empires, the context within which Hong Kong has been created); second, historical institutionalism (in order to look at the institutional machineries in Hong Kong which have served to allow elites to read and react to enfolding structural change); third, political-cultural analysis (in order to unpack the sets of ideas animating action, that is, the ways in which local agents have understood their circumstances and themselves); and fourth, political commentary (taken largely from the local press and serving to gloss the more formally derived argument).

4. Pursued by legal scholars: what is the legal status of the SAR? Where does authority lie (Beijing/Hong Kong)? How does Hong Kong fit into China's legal system? Which centre has authority over what spheres of social activity? See J.Y.S. Cheng ed. 2014 New Trends in Political Participation in Hong Kong, Hong Kong, City University Press.

5. The political system of China has been characterized in various ways - see, for example, F. Christiansen and S. Rai 1996 Chinese Politics and Society: An Introduction, Hemel Hempstead, Prentice Hall. Here the party-state is read in institutionalist terms, thus, it is a 'double bureaucracy'.

6. An issue noted in Kit Poon 2008 The Political Future of Hong Kong, London, Routledge.

7. A brief - and now famous - simple statement of this position was offered some forty years ago by C. Wright Mills 1970 The Sociological Imagination, Harmondsworth, Penguin, see the Annex.

8. C. Munn 2008 Anglo-China: Chinese People and British Rule in Hong Kong, 1841-1880, Hong Kong University Press.

9. S.K. Cheung 2012 'Hong Kong: geopolitics and intellectual practice' in Inter-Asia Cultural Studies 13.3.

10. The 'Hong Kong School' comprises local scholars whose work has (i) called attention to 'Hong Kong and its people'; (ii) looked at society and politics within Hong Kong; and (iii) puts the agency of local Chinese into the story of the colony (and its current development) - see Cheung 2012 pp. 340-41.

11. Cheung 2012 takes the notion of 'empire' from M. Hardt and A. Negri 2000 Empire, Harvard University Press.

12. On all this, see Susan Strange 1988 States and Markets, London, Pinter. In this text a sociological notion of structure is used, that is, a social structure is from the perspective of any one agent the sum total of what everyone else does - not fixed, but not readily malleable either.

13. On elites, see William Case 2002 Politics in Southeast Asia: Democracy or Less, London, Curzon. Here the focus is on the role of the elite as opposed to, say, popular democratic involvement (or other non-democratic systems). Case looks at a number of countries in Southeast Asia with plausible political histories but unfortunately conjoined to rather silly summary labels. 
14. It makes sense to speak of 'elites' - they hold the levers of power - but others read and react to change; for example, a significant number of the Hong Kong middle classes provided themselves with new foreign passports ahead of the 1997 handover.

15. A trio of notions glossing the work of Strange 1988. Strange wrote about the response of agents to global structures, pointing out that these structures were given for any one agent and that they obliged action. The present formulation is a simplification of that idea.

16. Pursued in P.W. Preston 1994 Discourses of Development, Aldershot, Avebury; P.W. Preston 1996 Development Theory, Oxford, Blackwell.

17. A sizeable group - the old and the poorly educated; the South China Morning Post (SCMP), November 2012, reported that the Gini Coefficient for the territory had gone above 0.5, making Hong Kong one of the most unequal developed territories in East Asia (the corollary was that many of the population did indeed live very poor lives).

18. The elite talk about 'the free market', the professional middle classes talk about being sensible, the grass roots talk about their difficulties (wages, housing), the poor inhabit a social world of cage homes and casual labour - Hong Kong is evidently class divided (see, for example, the Gini Coefficient). Others cut into the debate at different angles, so New Territory indigenous villagers talk about land rights.

19. In other words, Beijing does not speak with a single voice. On elite-level politics, see R. McGregor 2012 The Party: The Secret World of China's Communist Rulers, London, Penguin. The implication is that when local pro-Beijing groups say Beijing's pronouncements are just given they are in error - there is debate and so there is scope for further debate.

20. On nationalism, see C.R. Hughes 2006 Chinese Nationalism in the Global Era, London, Routledge; on ideas within Beijing's public sphere, see W. Callahan 2013 China Dreams: 20 Visions of the Future, Oxford University Press; on the nature of the party-state, see Y. Zheng 2010 The Chinese Communist Party as Organisational Emperor: Culture, Reproduction and Transformation, London, Routledge.

21. Recent treatments: Sung Y. W. 2005 The Emergence of Greater China: The Economic Integration of Mainland China, Taiwan and Hong Kong, London, Palgrave; S. Chiu and T.L. Lui 2009 Hong Kong: Becoming a Chinese City State, New York, Routledge.

22. One enduring lesson from dependency theory: groups that are powerful in the domestic scene may be subordinate or dependent figures in those wider networks within which they operate.

23. Illustratively, in the UK the elite stand in a superior relationship to members of the constituent nations of the territory, in an ambivalently equal relationship to members of the European Union (EU), but in a clearly subordinate relationship to the USA. This thought could be unpacked in an analysis of the structural conditions of the UK polity.

24. Taken from Strange 1988 - these would involve structures of production, finance, security and knowledge. In the case of Hong Kong there are several structural networks within which agents work: production (Hong Kong is a major manufacturer, with much of the factory activity relocated to Guangdong Province, and this relationship is important and finds a visible presence in the city in the form of logistics work; thus, the city is home to major sea and air port facilities); finance (Hong Kong is a major regional banking centre and this financial sector has an important and visible presence in domestic affairs); security (Hong Kong has an elaborate legal and police system, but it does not have armed forces; indeed, it is garrisoned by the People's Liberation Party (PLA)); knowledge (Hong Kong has major universities, active media (broadcast, print and film), science-park-based commercial research and so on - the role of the media is of particular note as it is generally taken to be less restricted than its mainland counterparts).

25. Strange 1988 .

26. International political economy is one recently fashionable restatement of the older tradition of political economy. It calls attention to the exchange of structures of power and the activities of various agents in order to uncover the logics of the extant global system see Strange 1988.

27. A. Giddens 1979 Central Problems in Social Theory, London, Macmillan. 
28. This is a conventional position, but the nature of the state has been much discussed, so too the matter of its effective reach within its domestic environments. In International Relations (IR) terms, there are three main theories - realist, liberalist and constructionist. With the last, analysis comes close to the notion of the social construction of state machineries (institutions) and more broadly the collective historical creation of the 'global system' - for more on this, see C. Hay 2002 Political Analysis, London, Palgrave.

29. E. Gellner 1983 Nations and Nationalism, Oxford, Blackwell; B. Anderson 1983 Imagined Communities, London, Verso; E. Hobsbawm 1990 Nations and Nationalism since 1780, Cambridge University Press.

30. Gellner 1983; Anderson 1983; and J. Habermas 1989 The Structural Transformation of the Public Sphere, Cambridge, Polity; and running the three together, states make nations, which are imagined communities that amongst other things create a public sphere in which collective issues can be addressed.

31. A. Acharya 2000 The Quest for Identity: International Relations of Southeast Asia, Oxford University Press - citing ideas of 'galactic' and 'mandala' polities, based on a core family/place with a shifting group of associated families/places.

32. On this, see P.W. Preston 2014 After the Empires: The Creation of Novel Political-Cultural Projects in East Asia, London, Palgrave.

33. In the run up to the handover, 1981-97, it was reclassified as a British Dependent Territory.

34. Quite how the PRC should be characterized is another issue. One suggestion is a 'civilization-state' - the state embraces or serves as an organizational vehicle for a civilization. The idea of nations is relatively new (Anderson), so laying claim to a national identity is something that could be done only recently, but it's not clear just who would claim to be a member of a civilization? The idea, however, does usefully point to the scale and history of the territory. David Goodman has remarked that China is not the name of a country, it's the name of a continent. Getting at the same issue, the PRC, which now occupies the territory of the Qing at its maximum extent, is large and diverse, which opens the way for multiple popular identifications (locale, network and memory).

35. J.M. Carroll 2005 Edge of Empires: Chinese Elites and British Colonials in Hong Kong, Harvard University Press.

36. Over the years, local academics have made simple surveys of self-identification, offering respondents a choice between 'Hong Konger' or 'Chinese', and whilst the balance shifts, the former is usually to the fore (see Hong Kong Transition Project at http://hktp.org).

37. This involves technical issues of citizenship - a Hong Kong person can carry a British National Overseas (BNO) passport or a Hong Kong SAR passport or a PRC passport. Many Hong Kong persons may have one or other of the first pair, plus a passport from overseas - say Canada. This is also distinct from subjective identification - who you think you are.

38. There might be other comparators - in Europe: Scotland, Catalonia, the Basque country or the Dutch speaking areas of northern Belgium.

39. Ideas of 'ethnicity' are widely used but they are problematical; grouping together members of a form of life in terms of how they look seems foolish - it seems to be a polite version of race identification but, obviously, forms of life are not determined by physiology.

40. Thus multiple languages, differences in climate, foods, histories and so on; more locally, for example, scripts - Hong Kong people use traditional script in contrast to mainland's simplified script - or Hong Kong people have maintained unbroken folk festivals only recently reintroduced in the mainland.

41. During most of the colonial era the border was more or less open - it was closed by PRC in the early 1950s. There have been subsequent waves of inward migration. It is an interesting issue as to how these inward migrants both keep hold of their pasts whilst becoming Hong Kongers - partly, generational, that is, since borders closed the resident population has cohered and used the mainland as an available 'other', a status it retains. 
42. Not just European - the Japanese Empire in Northeast Asia was dismantled by the Allied Powers and the American colony in the Philippines was reworked. The Americans and Australians kept some residual links with Pacific Island communities.

43. On this, see Preston 2014.

44. A point made by the PRC in articles 1 and 2 of the Joint Declaration - resuming, rather than accepting British restoration; see Tony Carty (HKU Legal Scholarship Blog - Tony Carty on International Standards in Hong Kong Political Reform - http://researchblog. law.hku.hk/2015 - May 132015.

45. T. Carty 2015 'Tony Carty on international standards in Hong Kong political reform' in HKU Legal Scholarship blog, May 132015.

46. Law Wing Sang 2009 Collaborative Colonial Power: The Making of the Hong Kong Chinese, Hong Kong University Press - chapters 7 and 8.

47. On this see C.A.G. Jones 2015 Lost in China: Law, Culture and Identity in Post-1997 Hong Kong, Cambridge University Press. The author builds the discussion around the idea of rule of law as a substitute for democratization and argues that Beijing's post-1997 project has been re-colonization - the deepening practical links plus Beijing's intransigence in regard to democratization point only in one direction; that said, the Hong Kong population is responding by asserting its own identity. On this see also A.S. Ku 2005 'Negotiating law, rights and civil autonomy' in A.S. Ku and N. Pun eds. Remaking Citizenship in Hong Kong: Community, Nation and the Global City, London, Routledge. The author notes that colonial government eschewed democracy for rule of law and this is now under pressure from Beijing and its local allies.

48. Mentioned in Poon 2008.

49. Law 2009; Poon 2008.

50. Kit Poon 2008 The Political Future of Hong Kong, London, Routledge, Chapter 1, points out that colonial discourse shifts from trusteeship to accountable government and that the colonial authorities pushed this from 1984 to 1997 (p.10). Poon thinks it all disingenuous, that is, they were covering themselves, but the social impact was real, that is, the Hong Kong population bought the idea.

51. Carroll 2005.

52. A gestural move, it would seem, in trying to recover the wider British Empire - on this see Gavin Ure 2012 Governors, Politics and the Colonial Office, Hong Kong University Press (see Chapter 6).

53. See Steve Tsang 2004 A Modern History of Hong Kong, Hong Kong University Press; Ure 2012.

54. Ure 2012 - on the role of unofficials in the colony's financial set up.

55. Ming Sing 2009 'Hong Kong's democrats hold their own' in Journal of Democracy 20.1.

56. D. Held 1987 Models of Democracy, Cambridge, Polity.

57. A. MacIntyre 1981 After Virtue, London, Duckworth.

58. C.B. Macpherson 1973 Democratic Theory: Essays in Retrieval, Oxford University Press.

59. J. Habermas 1989 The Structural Transformation of the Public Sphere, Cambridge, Polity.

60. The names mentioned point to the core of the intellectual counterpart of the modern world, but there are voices from other parts of the world, located differently within the broad evolving modern world - in East Asia, the counter-statement notion of 'Asian Values', plus numerous discussions of 'local models' of democracy.

61. In respect of East and Southeast Asia, see, for example, the work of the Australian School of Political Economy (Richard Higgot, Richard Robison, Kevin Hewison, Gary Rodan et al.); in a different vein, see William Case 1992 Politics in Southeast Asia: Democracy or Less, London, Curzon; or again in a different vein, the work of Chua Beng Huat on Singapore and Southeast Asia (B.H. Chua 1995 Communitarian Ideology and Democracy in Singapore, London, Routledge and B.H. Chua ed. 2009 Elections as Popular Culture in Asia, London, Routledge). In other words, a scholarly debate about the nature of 'democracy' in the region is up and running. 
62. The Young Plan was allowed to fall by the wayside by the local colonial authorities. Somewhat later, discussions with Beijing made it clear that Beijing opposed any change in the status quo and moves to dominion status would be met with force - see Ure 2012 Chapter 7.

63. On this, see Preston 1997.

64. Recently, there has been much discussion on the nature of the membership of diasporic communities; thus, for Hong Kong, there are new networks reaching to Australia and also to the Pacific coast of Canada.

65. See the work of Richard Hoggart 1958 The Uses of Literacy, Harmondsworth, Penguin.

66. Poon 2008.

67. The Asian Financial Crisis was occasioned by the over-rapid liberalization of local economies, exposing them to financial market speculation. Shifts in regional currency values triggered the crisis. American and European commentary was sanguine - where East Asia had been a success story it was now damned as merely the site of crony capitalism. The latter had its origins in cross-species infection that occurred in Guangdong Province. Local officials and Beijing initially denied that there was a problem - the epidemic was up and running before they acknowledged it. In the meantime, officials in Hong Kong did act but the disease cost Hong Kong around 300 deaths - and much disruption - all falling on the watch of the first CE - a businessman - Tung Chee Hwa.

68. Hong Kong has a well-entrenched elite; accusations of elite-level collusion are familiar. The public sphere in contrast is vigorous. The issue is its reach, that is, how effective can it be.

69. Thus, C.Y. Leung's interview comment around the time of his 2015 policy address that democracy would be risky as it might empower the poor - see 'C.Y. Leung: "Democracy would see poor people dominate Hong Kong vote"' in SCMP October 21 2014. See also S. Tiezzi 'Hong Kong's leader: universal suffrage threatens business interests' in The Diplomat October 21 2014; K. Bradsher and C. Buckley 'Hong Kong leader reaffirms unbending stance on elections' in New York Times October 202014 - Leung was quoted: '... if it's entirely a numbers game and numeric representation, then obviously you'd be talking to half the people in Hong Kong who earn less than $\$ 1,800$ a month $\ldots$ then you would end up with that kind of politics and policies.' 